DOI: 10.5604/01.3001.0013.2543

\title{
RESEARCH OF PARAMETERS OF FIBER-OPTICAL MEASURING SYSTEMS
}

\author{
Waldemar Wójcik ${ }^{1}$, Aliya Kalizhanova ${ }^{2,3}$, Gulzhan Kashaganova ${ }^{2,4}$, Ainur Kozbakova ${ }^{2,3}$, \\ Zhalau Aitkulov ${ }^{2,3}$, Zhassulan Orazbekov ${ }^{2,5}$ \\ ${ }^{1}$ Lublin University of Technology, ${ }^{2}$ Institute of Information and Computational Technologies, SR MES RK, ${ }^{3} \mathrm{Al}$-Farabi Kazakh National University, \\ ${ }^{4}$ Kazakh-American University, ${ }^{5}$ Abai Kazakh National Pedagogical University
}

\begin{abstract}
At present there exist a lot of technical devices, the failure of which can be connected not only with huge financial losses, but with the treat to the environment as well. Therefore, an important problem is the effective devices conditions diagnostics, including electronic components and check of their operation. Timely faults detecting allows introducing the prevention measures and avoiding serious consequences. Fiber-optic sensors have several advantages, more important of which include the immunity to electromagnetic disturbances, little weight and possibility to be included into the structure being measured. The most perspective are the sensors based on the Bragg fiber gratings. Bragg fiber gratings have several advantages, for instance, they allow creating the distributed measuring massifs, which contain several sensors. As well, they are insensitive to the optic power source vibrations. Variety of using the fiber sensors based on the Bragg fiber gratings has led to producing the Bragg fiber gratings with different spectral characteristics. Homogeneous Bragg fiber gratings have the spectra with solid side lobes, which can influence at the temperature sensor processing characteristics. To level the side lobes there is applied the apodization method, which is one of the means to affect the spectral form. The article herein considers the issues of the Bragg fiber gratings mathematical and computer modeling using the transfer matrix method. Transfer matrix method allows defining the optical components spectral characteristics based on the bound modes theory and description of electromagnetic wave, passing through an optic fiber. In the article there have been analyzed the Bragg fiber gratings in compliance with spectral features, such as transmission and reflectance spectra. As well, there has been carried out the experiment with influence of various parameters at the Bragg fiber gratings spectral characteristics. There have been studied the Bragg fiber gratings spectral features and selected the grating optimal parameters for designing the fiber-optic sensors based on the Bragg fiber gratings.
\end{abstract}

Keywords: Bragg gratings, optical sensors, temperature, mathematical model

\section{BADANIE PARAMETRÓW ŚWIATŁOWODOWYCH SYSTEMÓW POMIAROWYCH}

Streszczenie. Obecnie istnieje wiele urządzeń technicznych, których awarię można powiąać nie tylko z ogromnymi stratami finansowymi, ale także z troska o środowisko. Dlatego ważnym problemem jest skuteczna diagnostyka warunków pracy urzadzeń, w tym elementów elektronicznych i kontrola ich działania. Wykrywanie błędów w odpowiednim czasie umożliwia wprowadzenie środków zapobiegawczych i uniknięcie poważnych konsekwencji. Czujniki światłowodowe maja kilka zalet, z których ważniejsze to odporność na zakłócenia elektromagnetyczne, niewielka waga i możliwość właczenia do mierzonej struktury. Najbardziej perspektywiczne sa czujniki oparte na siatkach Bragga (FBG). Optyczne siatki Bragga maja kilka zalet, na przyktad umożliwiaja tworzenie rozproszonych układów pomiarowych, które zawieraja kilka czujników. Sa również niewrażliwe na wibracje źródła zasilania optycznego. Różnorodność wykorzystania czujników światłowodowych opartych na siatkach Bragga doprowadziła do wytworzenia siatek Bragga o różnych charakterystykach spektralnych. Jednorodne, optyczne siatki Bragga maja widma z petnymi płatkami bocznymi, które moga wpływać na charakterystyke przetwarzania czujnika temperatury. Aby wyrównać płatki boczne, stosuje się metodę apodyzacji, która jest jednym ze sposobów wplywania na forme widmowa. $W$ niniejszym artykule omówiono zagadnienia światłowodowych siatek Bragga, modelowania matematycznego $i$ komputerowego $z$ wykorzystaniem metody macierzy transferu. Metoda macierzy transferu pozwala na określenie charakterystyki widmowej składników optycznych w oparciu o teorie modów wiazanych i opis fali elektromagnetycznej, przechodzacej przez światłowód. W artykule przeanalizowano siatki Bragga zgodnie z cechami widmowymi, takimi jak widma transmisji i odbicia. Przeprowadzono również eksperyment z wpływem różnych parametrów na charakterystyki widmowe siatek Bragga. Zbadano cechy widmowe siatek Bragga $i$ wybrano optymalne parametry siatki do projektowania czujników światlowodowych opartych na siatkach Bragga.

Słowa kluczowe: siatki Bragga, czujniki optyczne, temperatura, model matematyczny

\section{Introduction}

Nowadays there are great many of technical devices, the failure of which can be connected not only with huge financial losses, but with the treat to the environment as well. Therefore, an important problem is the effective devices conditions diagnostics, including electronic components and check of their operation. Timely faults detecting allows introducing the prevention measures and avoiding serious consequences.

Measuring systems based on optic-electronic systems find application in the machines and processes diagnostics [12]. Separate place occupies the optic-fiber sensors, characterized by a number of advantages, amongst which the most important are the resistance to electric-magnetic disturbances and possibility of their building into the structure being measured [15]. In case of the sensor systems based on the Bragg fiber gratings' advantages are measurement accuracy self-sufficiency form, the light source fluctuation, the possibility of creating more complicated measuring systems, positioning several sensors on one optic fiber. Bragg fiber gratings in the sensitive applications are much sought after by the scientists all over the world during many years. Their basic feature is an ability to reflect the light radiation with welldefined wave length, with simultaneous transparency for the light with various waves lengths $[7,8]$.

Being based on defining the wave's relative central length offset, the fluctuations of the light source optic power does not affect its accuracy. There are a lot of methods for specifying the
Bragg wave length, as well, allowing its defining, based on the spectra with big noise $[2,14]$. Linear processing of the value having been measured upon transmitting the wave's standard length setoff, called the Bragg wave's central length, makes them natural transformers of physical values, such as power $[3,5,10]$, temperature or deformation $[11,13]$.

The parameter, making the certain influence at the Bragg grating spectrum is apodization. In the simplest case we differentiate homogeneous gratings, in which the modulation depth of interference fringes fracturing factor is the same along the structure's whole length. Multitude of the fiber-optic homogeneous structures definite applications made introducing the apodised function into their production methods, which led to modulation variable depth of grating fringes refraction index.

One of the most frequently used interrogation methods of temperature sensor based on the Bragg fiber gratings is the filtration by means of the second grating with the same wave length, having been created in the identical primary conditions [6]. In such system an important parameter, conditioning the given cyclical structure's practicality is the minimization of the so called side lobes [1]. One of the means to reach the effect thereof is the apodization through changing the modulation depth of refraction factor alterations in the core of the optical fiber along its axis. Cyclical structures production with any apodization functions often linked with the necessity to redesign the system and therefore the possibility to use mathematical models for simulating grating spectrum with a denoted apodization is justified. 


\section{Mathematical model of approximated Bragg gratings}

One of modeling techniques is the transfer matrix method (TMM) [4], which allows specifying the optic elements spectral characteristics based on the bounded modes theory and matrix describing the electro-magnetic wave, passing through the optic fiber following periods [9].

In such approach we suppose, that the grating overall length $L$ is broken down into exactly determined sections $N$, so that each section, having been created in such a manner with a length $\Delta z=L / N$, can be considered as homogeneous. Transmission matrix, describing the i- section will be defined as follows [17]:

$$
T_{i}=\left[\begin{array}{cc}
\cosh (\gamma \otimes z)-\frac{\sigma}{\gamma} \sinh (\gamma \otimes z) & -i \frac{k}{\gamma} \sin (\gamma \otimes z) \\
i \frac{k}{\gamma} \sin (\gamma \otimes z) & \cosh (\gamma \otimes z)-\frac{\sigma}{\gamma} \sinh (\gamma \otimes z)
\end{array}\right]
$$

For the definition above, it is also assumed, that $\kappa$ - variable, coupling factor constituent for refraction coefficient contrast ratio $v=1$, being analyzed wave's length $\lambda$ and envisaged apodization function $g$ will be $g(z)$ :

$$
\begin{gathered}
k=\frac{\Pi}{\lambda} \cdot v \cdot \hat{\sigma}_{\text {eff }}(z) \\
\bar{\delta}_{e f f}(z)=\delta_{e f f} \cdot g(z)
\end{gathered}
$$

During Bragg grating simulation the variable coupling ratio component value $\kappa$ depends on the selecting the refraction factor envelope function (2). General coupling coefficient is defined with the equation (4). It is as well known, that $\lambda_{B}-$ Bragg wave length, and $n_{\text {eff }}$-effective refraction factor.

$$
\begin{gathered}
\hat{\sigma}=\delta+\sigma-\frac{1}{2} \frac{d \varphi}{d z} \\
\delta=2 \prod n_{e f f}\left(\frac{1}{\lambda} \cdot \frac{1}{\lambda_{B}}\right)
\end{gathered}
$$
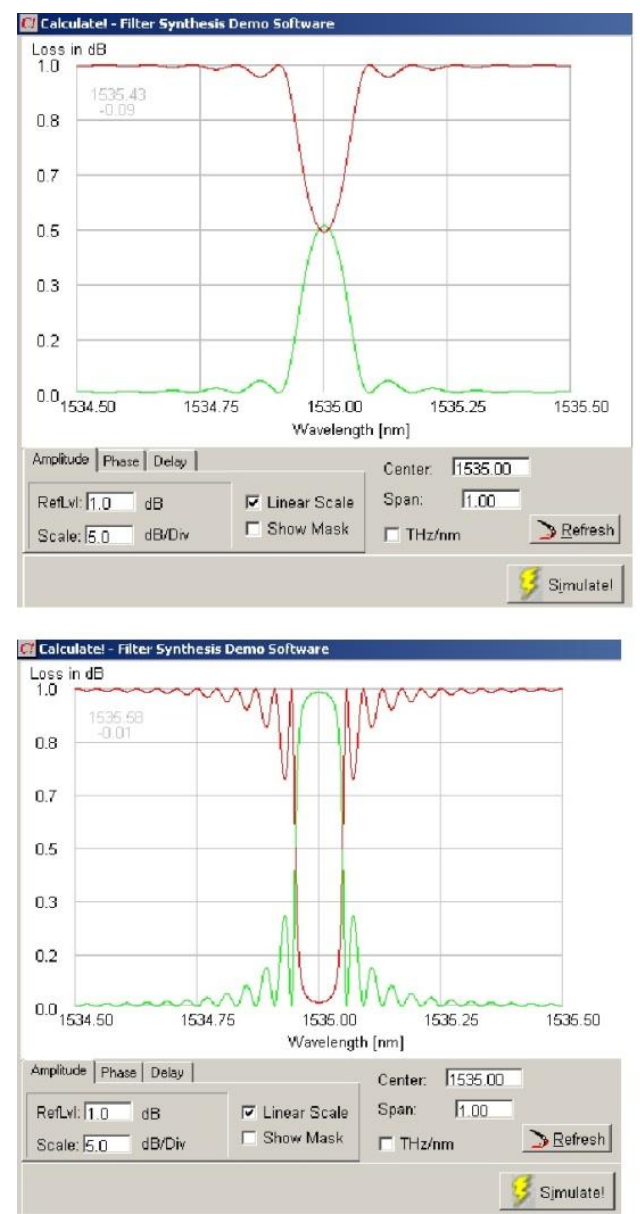

$$
\sigma=\frac{2 k}{v}
$$

Parameter $\gamma$ for transmission matrix is specified as follows:

$$
\gamma=\sqrt{k^{2}+\hat{\sigma}^{2}}
$$

Overall grating features can be described as

$$
\begin{gathered}
{\left[\begin{array}{l}
R_{0} \\
S_{0}
\end{array}\right]=T\left[\begin{array}{l}
R_{N} \\
S_{N}
\end{array}\right]} \\
T=\left[T_{N}\right] \cdot\left[T_{N-1}\right] \cdots\left[T_{3}\right] \cdot\left[T_{2}\right] \cdot\left[T_{1}\right]
\end{gathered}
$$

Values of matrix parameters $T$ might be used for defining characteristics of both reflected (10), and transmitted (11) waves. Further the indexed components $T_{i j}$ indicate the elements values under the $i$-column and $j$-line of transmission matrix.

$$
\begin{aligned}
& R=\frac{T_{21}}{T_{11}} \\
& S=\frac{1}{T_{11}}
\end{aligned}
$$

\section{Modelling spectral characteristics using simulation original application}

Comprehension of the Bragg fiber gratings features and basic parameters is possible without their production. However, for that purpose the modeling instruments are necessary. Their usage can minimize the abnormal grating creation, also adjust it to a targetoriented application early enough. Apodization function proper selection allows optimize additionally the grating features with account of its target-oriented application site, for instance, as an optic filter or measuring sensor [16].

Own-grown simulation instrument based on TMM mathematical model has been used for modeling the transmission spectrum change for Bragg different length gratings.

In view of that there was used the Bragg grating with a wave length of $1550 \mathrm{~mm}$ and with an effective refraction factor 1.447 . Simulation outcomes are presented on the Fig. 1.
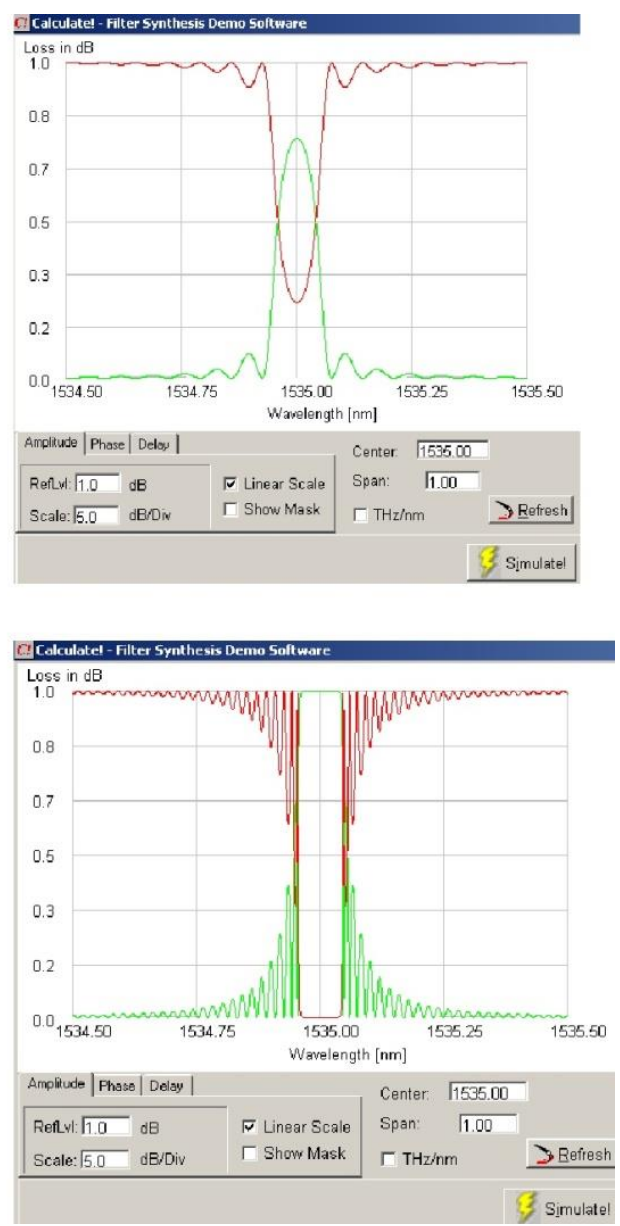
Legality of the used instrument has been proved with additional simulations for Bragg various waves' lengths (1546 nm, $1550 \mathrm{~nm}$ ). Observations outcomes have been placed on sequential graphs, Fig. 2.

Presented opportunities are only a part of modeling accessible parameters. It is possible to define the apodization function, being used upon Bragg gratings recording. But the topic will be discussed in detail in one of the following subsections of the article herein.
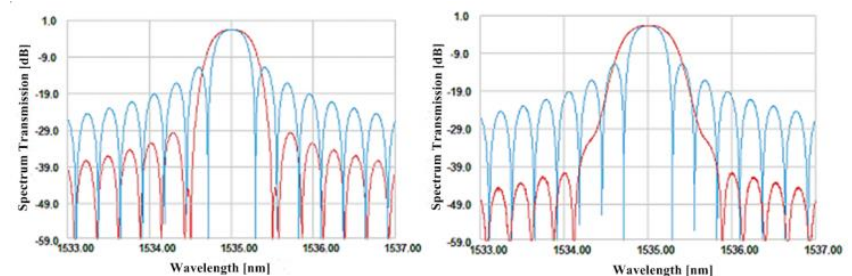

Fig. 2. Transmission spectrum for Bragg various wavelengths (1546 nm, $1550 \mathrm{~nm})$

\section{Optical system mathematical and physical models}

Optical systems simulation using computer instruments, based on mathematical models, can turn out to be very useful, but it is worth to get a sense, that a computer language is not able to reproduce completely the physical optical system and all prevailing physical phenomena. The article section herein compares the features being simulated to the real reflection spectrum. It has been specified, to what extent the object being simulated can differ from the actual system.

Within the experiment frame the Bragg grating has been built up in the system, similar to the one, that is shown on the Figure 3. There has been applied a phase mask with constant period along its overall length. Laser with a profile bundle, introducing apodization with the function, being defined with the formula (12), has been used for combustion of the sequential structure in the optic fiber core. Figure 3 shows, that a reflected spectrum has been measured using a spectrum analyser with a reduction $0.02 \mathrm{~nm}$.

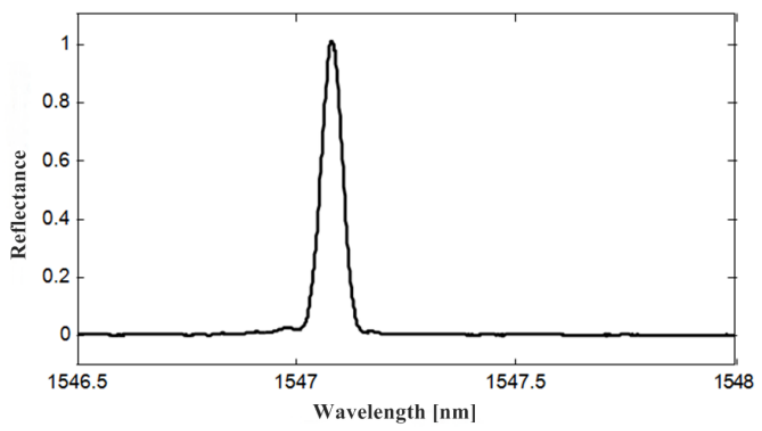

Fig. 3. Real optic system reflectivity spectrum

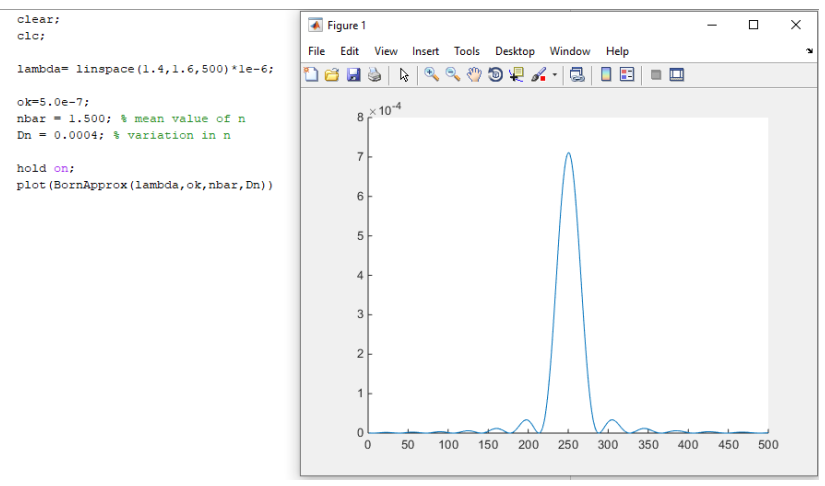

Fig. 4. Apodization grating simulated reflectivity spectrum in compliance with laser beam profile
In case of mathematical model, as input data for modeling instrument, there have been introduced analog grating parameters (there has been accounted the previously set apodization function). Outcomes of the modeling herein are presented on the Figure 4.

Comparing the spectrum, shown on the Figure 3, and simulation characteristics, demonstrated on the Figure 4, clearly prove compatibility of the Bragg grating nature with the model being used in the application. Both characteristics go with the fact, that applying the apodization with a profile, compatible with Gaussian curve with accordingly selected parameters, brings to disappearance of the side lobes, typical for homogeneous Bragg fiber gratings.

\section{Temperature sensor processing characteristics}

Measurements for the sensor temperature sensitivity definition are based on the Bragg wavelengths, considering the spectral characteristics, having been measured within different temperatures range. The most frequently used method of the central wavelength definition is the extemum search (minimum for transmission spectrum or maximum for reflectivity one). Figure 5 shows the measuring system scheme, in which the climatic chamber has been used for the temperature setting. During measurements the relative humidity has been maintained constant at the level of $30 \%$.

The graph on the figure 5 shows the tested temperature sensor processing characteristics together with the linear regression line, obtained based on the measurement points.

Linear correlation factor, having been obtained for characteristics points in the measured temperature range, equals to $r=0.9997$ and standard deviation $s=0.473$. Those parameters show, that the temperature changes along the Bragg wavelength, and it is linear. System's sensitivity, realized as the central wavelength shifting to 1 degree Celcium, can be expressed as the difference ratio in the Bragg wavelengths, at measured temperatures to the temperatures differentials:

$$
\frac{\Delta \lambda_{B}}{\Delta T}=\frac{\lambda_{T 1}-\lambda_{T 2}}{T_{1}-T_{2}}
$$

Sensitivity $S$ of the sensor being tested is defined as follows

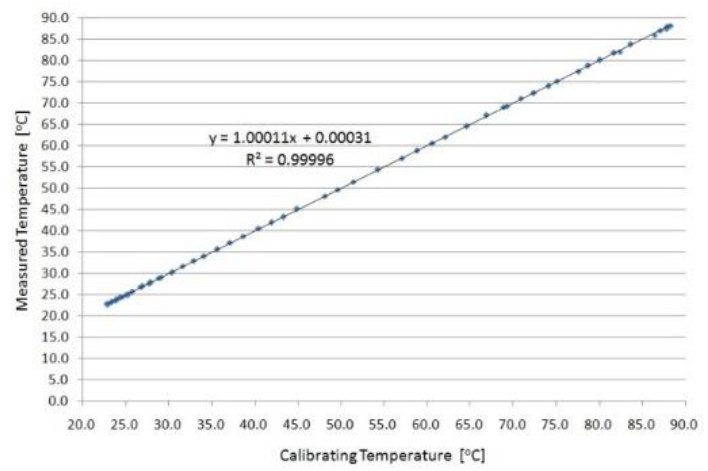

Fig. 5. Characteristics of temperature sensor processing

\section{Conclusion}

Physical multitudes fiber-optic sensors occupy an important place in the sensors area thanks to a few of advantages, which differentiate them from electronic analogs. A special type is a sensor on the basis of the Bragg fiber-optic gratings, which apart from the standard function, characterizing the opto-fiber sensors, also allows multiplexing, which creates a wide network, consisting of dozens sensors, placed in one optic fiber.

A great many applications for the Bragg fiber gratings brought to the necessity to influence at the grating optic spectrum nature. Upon temperature measuring the selection criterion consists in the most effective reduction of the so-called side lobes, presence of which might severely affect the sensors' characteristics, particularly while using interrogation filtration system. One of the 
means to eliminate the spectrum unfavorable features is apodization, commonly including the refraction index change depth modulation along the structure. Applying the mathematical model, taking into consideration the apodization function and own simulation application function, allows forecasting the influence of apodization parameters change at the outlet spectrum. Examples show the effect of selected inlet modeling parameters at the form of the outlet characteristic.

The quality of the model, used in simulations, has been checked through comparing the characteristics, having been measured for actual Bragg grating with apodization, transmitted by laser beam profile to a resulting modeling outcome for introduced apodization function, corresponding to laser beam power distribution. Both characteristics show clear suppression of the side lobes, adding the Gaussian character of the basic peak spectrum

The Bragg fiber grating, used as a temperature sensor, secures the being measured linear characteristic for shifting the grating wavelength. The experiment, fulfilled for the formulated grating, allowed defining its temperature sensitivity, which constitutes $10.37 \mathrm{~h} /{ }^{\circ} \mathrm{C}$. There has been confirmed the temperature processing linear character for shifting the Bragg wavelength, which is proved with the statistical parameters denoted characteristics.

Experimental studies have been conducted in the optoelectronic laboratories of the Lublin University of Technology, Faculty of Electrical Engineering and Computer Science in the frame of the state financing project No AP05132778 "Research and development of interrogation signals system with optic-fiber refractometer using the telecommunication networks" IICT SR MES RK.

\section{References}

[1] Abdulina S. R., Vlasov A. A.: Suppression of side lobes in the Bragg fiber grating reflection spectrum. Optoelectronics, Instrumentation and Data Processing 50(1)/2014, 75-86.

[2] Chen Y., Chen L., Liu H., Wang K.: Research of FBG sensor signal wavelength demodulation based on improved wavelet transform. Optic 124/2013, 48024804

[3] Cięszczyk S., Kisała P.: Inverse problem of determining periodic surface profile oscillation defects of steel materials with a Bragg fiber grating sensor. Appl. Opt. 55/2016, 1412-1420.

[4] Demirdag O., Yildirim B.: Comparing transmission matrix method and AN- FIS in free vibration analysis of Timoshenko columns with applications. Res. Eng. Struct. Mat. 2/2016, 1-18

[5] Harasim D., Gulbakhar Y.: Improvement of FBG peak wavelength demodulation using digital signal processing algorithms. Proc. SPIE 9662, 2015, 966212.

[6] Harasim D., Kisała P.: Układy przesłuchujące multipleksowane światłowodowe czujniki Bragga. Informatyka, Automatyka, Pomiary w Gospodarce i Ochronie Środowiska - IAPGOS 5(4)/2015, 77-84.

[7] Kashyap R.: Fiber Bragg Gratings. Academic Press San Diego 2009.

[8] Kenneth O., Meltz G.: Bragg Fiber Grating Technology Fundamentals and Overview. Journal of Lightwave Technology 15(8)/1997, 1263-1276.

[9] Khalid K. S., Zafrullah M., Bilal S. M., Mirza M. A.: Simulation and analysis of Gaussian apodized Bragg fiber grating strain sensor. Journal of Optical Technology 7(10)/2012, 667-673.

[10] Kisała P., Cięszczyk S.: Method of simultaneous measurement of two direction force and temperature using FBG sensor head. Applied Optics 54(10)/2015, 2677-2687.

[11] Kisała P.: Method of simultaneous measurement of bending forces and temperature using Bragg gratings. Proc. SPIE 9506, 2015.

[12] Kotyra A.: Optoelektroniczne systemy w zastosowaniach diagnostycznych pomiarowych. Informatyka, Automatyka, Pomiary w Gospodarce i Ochronie Środowiska - IAPGOS 4(2)/2014, 9-10.

[13] Majumder M., Gangopadhyay T. K., Chakraborty A. K., Dasgupta K., Bhattacharya D. K.: Bragg fiber gratings in structural health monitoring present status and applications. Sensors and Actuators 147/2008, 150-164.

[14] Negri L., Nied A., Kalinowski H., Paterno A.: Benchmark for Peak Detection Algorithms in Bragg Fiber Grating Interrogation and a New Neural Network for its Performance Improvement. Sensors 11/2011, 3466-3482.

[15] Pereira G., McGugan M., Mikkelsen L.P.: Method for independent strain and temperature measurement in polymeric tensile test specimen using embedded FBG sensors. Polymer Testing 50/2016, 125-134.

[16] Wójcik W., Kisała P.: The application of inverse analysis in strain distribution recovery using the Bragg fiber grating sensors. Metrology and Measurement Systems 16(4)/2009, 649-660.

[17] Wójcik W., Kisała P.: Metoda wyznaczania funkcji apodyzacji światłowodowych siatek Bragga na podstawie ich charakterystyk widmowych Przegląd Elektrotechniczny 86(10)/2010, 127-130.
Prof. Waldemar Wójcik

e-mail: waldemar.wojcik@pollub.pl

Director of Institute of Electronic and Information Technologies, Faculty Electrical Engineering and Computer Science, Lublin University of Technology. His research interests include electronics, automatics, advanced control techniques, the optimization of the industrial processes, and fiber optic sensors including fiber Bragg gratings.

ORCID ID: 000-0002-0843-8053

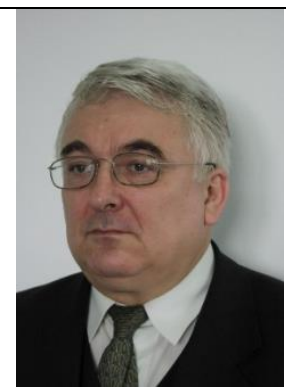

\section{Ph.D. Aliya Kalizhanova}

e-mail: kalizhanova_aliya@mail.ru

Candidate of physical and mathematical sciences, associate professor, the deputy general director of the Institute of Information and Computationa Technologies of the Ministry of Education and Science CS of the Republic of Kazakhstan. Scientific interests of the leader: mathematical modeling of systems, models of transport systems network analysis, optimization methods, technologies for developing sensor systems for signals receivetransmit, mathematical modeling of Bragg fibe gratings.

ORCID ID: 000-0002-0843-8053

\section{Ph.D. Gulzhan Kashaganova}

e-mail: guljan_k70@mail.ru

Ph.D. on a specialty "Radio engineering, electronics and telecommunications" the senior scientific employee of Institute of Information and Computational Technologies of the Ministry of Education and Science CS of the Republic of Kazakhstan. Scientific interests: protection of information in telecommunication networks, optical fiber in telecommunication systems and networks, technologies for development of sensor systems for receiving and transmitting signals, mathematical modeling of Bragg fiber gratings.

ORCID ID: 0000-0001-8150-1621

\section{Ph.D. Ainur Kozbakova}

e-mail: ainur79@mail.ru

Ph.D. on a specialty "Information Systems", a senior fellow at the Institute of Institute of Information and Computational Technologies of the Ministry of Education and Science CS of the Republic of Kazakhstan. Research interests: mathematical modeling of discrete systems, evacuation tasks, operations research, technology design of complex systems.

\section{ORCID ID: 0000-0002-5213-4882}
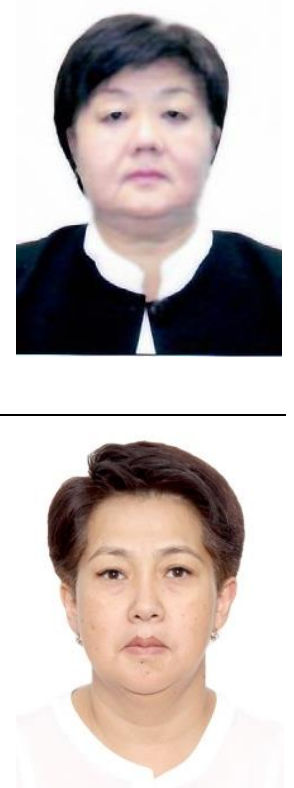

\section{M.Sc. Zhalau Aitkulov}

Doktorant Ph.D. on a specialty "Information Systems", a programmer at the Institute of Institute of Information and Computational Technologies of the Ministry of Education and Science CS of the Republic of Kazakhstan. Research interests: mathematical modeling of discrete systems, evacuation tasks, operations research, technology design of complex systems.

\section{ORCID ID:0000-0002-5928-3258}

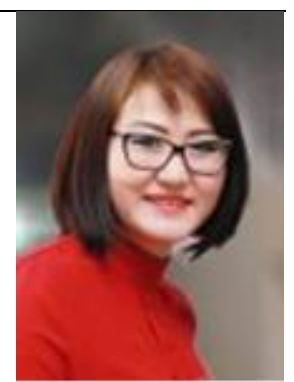

\section{Ph.D. Zhassulan Orazbekov}

e-mail: o.jas@mail.ru

Ph.D. on a specialty "Information Systems", a senior fellow at the Institute of Institute of Information and Computational Technologies of the Ministry of Education and Science CS of the Republic of Kazakhstan. Research interests: mathematical modeling of discrete systems, operations research, technology design of complex systems.

ORCID ID: 0000-0003-4332-1966
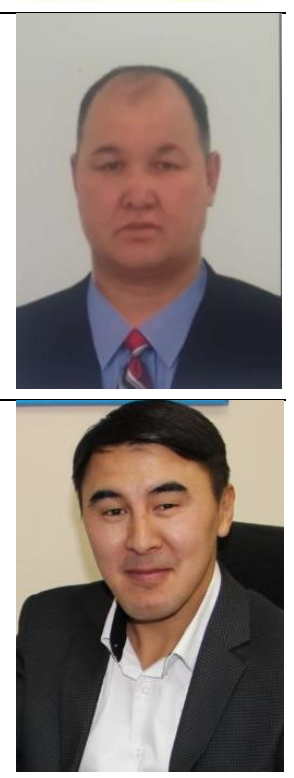

otrzymano/received: 15.05 .2019

przyjęto do druku/accepted: 15.06 .2019 